\title{
Inter-annual Changes of Water Temperature in the Southern South China Sea's Continental Shelf: The Influence of ENSO on Malaysian Waters
}

\author{
Afifi Johari \\ Mohd Fadzil Akhir \\ Institute of Oceanography and Environment, Universiti Malaysia Terengganu, Malaysia \\ Muhammad Naim Satar \\ Institute of Oceanography and Environment, Universiti Malaysia Terengganu, Malaysia \\ Zuraini Zainol \\ Institute of Oceanography and Environment, Universiti Malaysia Terengganu, Malaysia \\ Guo Jingsong \\ First Institute of Oceanography, State Oceanic Administration, Qingdao, China
}

Institute of Oceanography and Environment, Universiti Malaysia Terengganu, Malaysia, afifijohari17@gmail.com

Follow this and additional works at: https://jmstt.ntou.edu.tw/journal

Part of the Fresh Water Studies Commons, Marine Biology Commons, Ocean Engineering Commons, Oceanography Commons, and the Other Oceanography and Atmospheric Sciences and Meteorology Commons

\section{Recommended Citation}

Johari, Afifi; Akhir, Mohd Fadzil; Satar, Muhammad Naim; Zainol, Zuraini; and Jingsong, Guo (2021) "Inter-annual Changes of Water Temperature in the Southern South China Sea's Continental Shelf: The Influence of ENSO on Malaysian Waters," Journal of Marine Science and Technology. Vol. 29: Iss. 4, Article 12.

DOI: 10.51400/2709-6998.1593

Available at: https://jmstt.ntou.edu.tw/journal/vol29/iss4/12

This Research Article is brought to you for free and open access by Journal of Marine Science and Technology. It has been accepted for inclusion in Journal of Marine Science and Technology by an authorized editor of Journal of Marine Science and Technology. 


\title{
Inter-annual Changes of Water Temperature in the Southern South China Sea's Continental Shelf: The Influence of Enso on Malaysian Waters
}

\author{
Afifi Johari ${ }^{a}$, Mohd Fadzil Akhir ${ }^{a, *}$, Muhammad Naim Satar ${ }^{a}$, \\ Zuraini Zainol ${ }^{a}$, Guo Jingsong ${ }^{b}$ \\ ${ }^{a}$ Institute of Oceanography and Environment, Universiti Malaysia Terengganu, 21030 Kuala Nerus, Terengganu, Malaysia \\ ${ }^{\mathrm{b}}$ First Institute of Oceanography, State Oceanic Administration, Qingdao 266061, China
}

\begin{abstract}
An extensive amount of data from the World Ocean Database (WOD) that covers the southern South China Sea (SSCS) were analysed to study the long-term trends and variations of the El-Nino Southern Oscillation (ENSO) event. The WOD data were selected from 1951 to 2010 , which included the area within $0-10{ }^{\circ} \mathrm{N}$ and $100-117{ }^{\circ} \mathrm{E}$. El-Nino and La-Nina anomaly results showed that the sea surface temperature anomalies (SSTa) trend of SSCS was higher during offset-ElNino years and lower during offset-La-Nina years. Besides, the inter-annual vertical water temperature profile revealed that the deepening of the warmer water temperature occurred in February and August of the offset-El-Nino years. Next, analysis of the potential area for coastal upwelling showed that the uplifting of cold water $\left(26{ }^{\circ} \mathrm{C}\right)$ at the east coast of Peninsular Malaysia (ECPM) occurred during the peak southwest monsoon, whereas at the northwest of Sabah waters (NWSW), it occurred during the offset northeast monsoon. El-Nino suppressed the coastal upwelling at the ECPM due to the intense mixing of warm water during the offset-El-Nino years. Meanwhile, El-Nino enhanced the coastal upwelling in the NWSW due to the establishment of a positive wind stress curl anomaly at the northwest Borneo coast.
\end{abstract}

Keywords: Coastal upwelling, ENSO, Inter-annual variability, Southern south China Sea

\section{Introduction}

$\mathrm{H}$ orizontal advection is important, especially to the ocean heat content during the mature phase of the El-Nino Southern Oscillation (ENSO) event [24]. In general, the upper layer circulation in the southern South China Sea (SSCS) shows discrete seasonal characteristics during the northeast and southwest monsoons, where cyclonic circulation occupies the South China Sea (SCS) basin during the northeast monsoon or occupies and joins the northern and southern cyclonic gyres during the southwest monsoon [41]. These cyclonic gyres accompanied by the intensification of the SCS
Western Boundary Current (SCSWBC) play a key role in the relocation of SCS water properties, heat, and energy [30]. During El-Nino events, the strength of the northeast monsoon reduces, resulting in a weaker cyclonic basin-scale circulation in the SCS, especially the SSCS $[29,30,39,41]$.

Apart from the circulation, ENSO also regulates the Southeast Asian rainfall anomalies [28,38]. In normal years, during the northeast monsoon, the south of China receives a limited rainfall due to strong north-easterly winds in the lower troposphere, which carry the southward cold and dry air masses into the SCS [20,29]. Nevertheless, El-Nino events induce the weakening of the winter monsoon 
in the SCS through the transportation of cold and dry air masses from the north of SCS to the south of China, causing a high rainfall rate there $[29,37,40]$.

Furthermore, a few studies have reported that in the SSCS, water temperature features such as the sea surface temperature anomalies (SSTa) and mixed layer depth (MLD) are largely influenced by the ENSO event $[8,21,27,38,42]$. The inter-annual SSTa in the SSCS is altered by El-Nino and is either atmospheric or oceanic driven, in which double peaks evolution of SSTa are recorded in February and August during El-Nino years due to shortwave radiation and net heat flux as well as meridional geostrophic heat advection, respectively [27]. On the other hand, the MLD is usually deepened during the El-Nino event [21].

Coastal upwelling is a unique feature in the SSCS [10]. During the southwest monsoon, prevailing alongshore south-westerly wind generates the offshore Ekman transport and positive wind stress curl enhances the upwelling formation along the east coast of Peninsular Malaysia (ECPM) $[16,17,35,36]$. Meanwhile, during the northeast monsoon, north-easterly monsoon wind dominates the northwest of Borneo and blows along the coastline, which creates a wind jet with a positive wind stress curl off the coast of northwest Borneo due to orographic blockage of the mountains [32]. Regarding the possible connection with ENSO, there are records of the weakening of coastal upwelling at the ECPM caused by the suppression of El-Nino due to the coupled actions of the northerlies with stratification and atmospheric circulation $[8,16]$. In contrast, coastal upwelling in the northwest of Sabah waters (NWSW) was documented to be enhanced by the El-Nino events [1,5,32], where anticyclonic winds and positive wind stress curl anomalies are strengthened in the northwest of Borneo during the northeast monsoon in El-Nino years [32].

Investigation of coastal upwelling in the SSCS was started in the 2000s. Specifically, the study on coastal upwelling at the ECPM was initiated by [4] using satellite imaging from 2000 to 2012 to identify the cold patch area that indicated upwelling formation [18]. further examined coastal upwelling by observing the thermal frontal variability in the ECPM from 2000 to 2013 through satellite imaging. Then [35,36], documented the influence of upwelling on the thermohaline and nutrient concentration in the ECPM in 2014 via in-situ data collection. Next, using data from 2000 to 2013 [17], identified the main factors that contributed to the formation of coastal upwelling in the northern, middle, and southern parts of ECPM. At the NWSW, research on coastal upwelling was conducted by [1,2]; who discovered that this area recorded the highest chlorophyll- $a$ (chl- $a$ ) concentration during the northeast monsoon. On the other hand [5], documented the intensity of upwelling in the whole of Sabah's waters, while [32] managed to record the increase of upwelling in the NWSW due to the ElNino event.

Despite all the available knowledge, there is no detailed study on the water temperature profile of SSCS pertaining to El-Nino, particularly from 1990 and earlier. Therefore, this study attempts to determine the relationship between ENSO and water temperature variability that could affect the changes in upwelling features in the SSCS. Besides, most previous studies on Sabah waters only observed the presence of upwelling through the chl$a$ indicator but had failed to capture the temperature drop during this event. Thus, the exploration of insitu data from WOD performed in this current study will be beneficial in describing upwelling based on the temperature profile observation.

\section{Materials and methods}

\subsection{Data acquisition}

The study sites were selected based on the data distribution acquired from WOD (Fig. 1). The chosen years are listed in Table 1. Datasets from the Malacca Strait, Karimata Strait, and Java Sea areas were excluded in this study. Furthermore, only datasets from February, April, and August were used for the inter-annual temperature profile analysis. Three transects were selected for the vertical temperature profile analysis (Fig. 1b), where T1 was located at the centre of SSCS, T2 was located at the south of ECPM, and T3 was located at the NWSW. These transects were chosen due to its fair distribution on the spatial and temporal resolutions during the study period.

\subsection{Data collection}

Data extracted from the WOD covered the area between 0 and $10{ }^{\circ} \mathrm{N}$ and $100-117^{\circ} \mathrm{E}$. The data were taken from WOD since the database is very reliable for long-term and large spatial research $[13,19,22,23,33,34]$. Domain selection was processed using the Ocean Data View (ODV) software accompanied by the bathymetry data from GEBCO 2014. Then, screening for error data was conducted, after which, the number of datasets in the study area was reduced to 23,252 from 25,864 (a 10\% cut). In this study, the non-selective parameter (other 
(a)

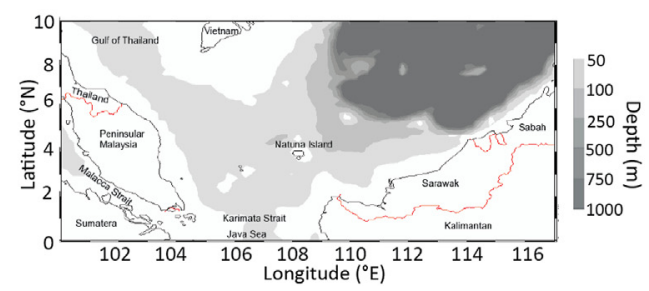

(b)

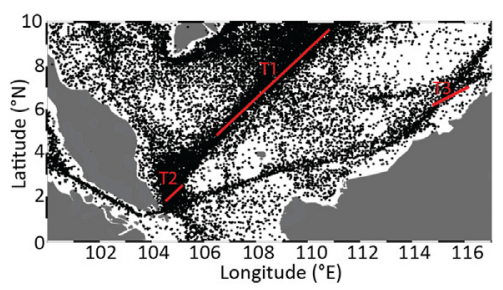

Fig. 1. (a) Bathymetry map of the SSCS and (b) data distribution in the study areas. The total number of datasets was 23,252. The red lines indicate the transect for the vertical temperature analysis. Note: Refer to Table 1 and Appendices 1 and 2 for spatial and temporal data details.

Table 1. Details of the selected transects.

\begin{tabular}{llllll}
\hline Transect & Location & Month & Year & Period & $\begin{array}{c}\text { No. of datasets } \\
\text { along the transect }\end{array}$ \\
\hline T1 & Centre of SSCS & February & 1972 & Onset-El-Nino & 10 \\
& & February & 1973 & Offset-El-Nino & 35 \\
& & February & 1982 & Onset-El-Nino & 17 \\
& & February & 1983 & Offset-El-Nino & 20 \\
& & August & 1976 & Offset-La-Nina & 7 \\
T2 & August & 1983 & Offset-El-Nino & 11 \\
& & August & 1965 & Onset-El-Nino & 9 \\
T3 & ECPM & August & 1966 & Offset-El-Nino & 12 \\
& & April & 1966 & Offset-El-Nino & 8 \\
\hline
\end{tabular}

than temperature) was excluded during the data extraction. Selection for the spatial and temporal study was made based on the distribution of the datasets.

On the other hand, the SSTa indices for Nino $1+2,3,3.4$, and 4.0 regions were acquired from the National Oceanographic and Atmospheric Administration (NOAA). The data were retrieved from https://www.esrl.noaa.gov/psd/gcos_wgsp/

Timeseries. The Nino SSTa indices are the temperature anomaly indices in the Nino regions that are captured using the HadlSST1 dataset and processed by the NOAA. Nino 3.4 SSTa index was used to identify the significant El-Nino and La-Nina years. The SSTa in Nino 3.4 region greater than $0.5^{\circ} \mathrm{C}$ and lesser than $-0.5{ }^{\circ} \mathrm{C}$ in six consecutive months were considered as El-Nino and La-Nina years, respectively [28]. The results pertaining to the ENSO events are tabulated in Table 2.

To gain a better understanding of upwelling and the effects of ENSO on upwelling, daily $10 \mathrm{~m}$ wind data from both the $\mathrm{u}$ and $\mathrm{v}$ components were obtained from the National Centers for Environmental Prediction (NCEP) and National Center for Atmospheric Research (NCAR). The NCEP/NCAR Reanalysis 1 is a joint project to produce a continuously updated global gridded dataset that represents the state of the Earth's atmosphere, incorporating observations and numerical weather prediction (NWP) model output from 1948 until the present. Analysis of the monthly wind data was conducted using the MATLAB software through the selection of data with similar dates as the WOD data for the upwelling study. A detailed analysis of the data from February and August 2009-2010 was performed to investigate the effect of ENSO on upwelling.

For supplementary data, monthly SST readings from the Moderate Resolution Imaging Spectroradiometer (MODIS) onboard the Aqua satellite was extracted from the Ocean Colour website. This satellite is viewing the Earth's entire surface every 1-2 days, acquiring data in 36 spectral bands or groups

Table 2. The average of SSTa, standard deviation, and correlation coefficient of selected El-Nino/La-Nina years against the El-Nino 2009/2010 year based on the Nino 3.4 SSTa index.

\begin{tabular}{lllllll}
\hline Year & $1965 / 1966$ & $1972 / 1973$ & $1973 / 1974$ & $1975 / 1976$ & $1982 / 1983$ & $1997 / 1998$ \\
\hline Average SSTa $\left({ }^{\circ} \mathrm{C}\right)$ & 0.42 & 0.06 & -0.80 & -0.57 & 0.68 & 0.63 \\
Standard deviation $\left({ }^{\circ} \mathrm{C}\right)$ & 0.68 & 1.28 & 0.92 & 0.82 & 1.09 & 1.33 \\
Correlation coefficient & 0.87 & 0.95 & -0.66 & -0.92 & 0.96 & 0.97 \\
ENSO category & El-Nino & El-Nino & La-Nina & La-Nina & El-Nino & El-Nino \\
\hline
\end{tabular}


of wavelengths. For this study, level $3,4 \mathrm{~km}$ resolution, and $11 \mu$ daytime SST data from February and August during the ENSO years 2009-2010 were selected.

\subsection{Data analysis}

The monthly average of SST $(10 \mathrm{~m})$ in SSCS was taken from January 1951 until December 2010. Next, the SSTa was calculated by looking at the difference between an actual value and a long-term average value, as shown in Equation (1).

SSTa $=$ SSTx - SSTy (SSTa)

where, SSTx is the average SST of the observed month and SSTy is the long-term average SST of the observed month (an average over many years). Next, the SSTa was smoothed using the five-month moving average method. After that, an analysis was performed to demonstrate the SSTa trend during the offset-El-Nino and offset-La-Nina years.

To observe the variation of vertical water temperature, the contour plot of the vertical water temperature of the selected transects was drawn. This was carried out to describe the difference between the vertical water temperature profiles of the selected transects during the ENSO events.

For the statistical analysis, Spearman's rank correlation was used to observe the possible relationship between ENSO and the SSCS region since the data obtained in this study did not follow a normal distribution. The correlation coefficient is a measurement that determines the degree to which two variables' movements are associated. The range of values for the correlation coefficient is -1.0 to 1.0. A correlation of -1.0 indicates a perfect negative correlation, while a correlation of 1.0 indicates a perfect positive correlation. The equations to calculate the correlation, covariance, and variance are as follows:

$\rho_{X Y}=\frac{\operatorname{cov}(X, Y)}{\sigma_{X} \sigma_{Y}}($ Correlation $)$

$\operatorname{cov}(X, Y)=\frac{\sum_{i=1}^{n}\left(X_{i}-\bar{X}\right)\left(Y_{i}-\bar{Y}\right)}{n-1}($ Covariance $)$

$\sigma_{X}=\sqrt{\frac{\sum(\mathrm{X}-\overline{\mathrm{X}})^{2}}{\mathrm{n}-1}}($ Variance $)$

where, $\mathrm{X}$ is the dependent variable, $\mathrm{Y}$ is the independent variable, $X^{-}$is the mean of the dependent variable $X, Y^{-}$is the mean of the independent variable $Y$, and $n$ is the number of data points in the sample. In this analysis, $X$ referred to the SSTa of SSCS from WOD, whereas $Y$ was the SSTa indices in the Nino regions from the NOAA website.

\section{Results}

\subsection{SSTa in SSCS related to ENSO events}

The year 2009/2010 was chosen as the reference year of the El-Nino event since it recorded the warmest sea temperature $[15,16]$. Based on the correlation coefficient analysis of the SSTa index for 2009/2010 and the other El-Nino years, four strong El-Nino years (1965/1966, 1972/1973, 1982/1983, 1997/1998) and two strong La-Nina years (1973/1974, 1975/1976) were noted, as tabulated in Table 2.

The highest correlation coefficient with El-Nino $2009 / 2010$ was recorded in the year 1997/1998, followed by 1982/1983, 1972/1973, and 1965/1966. On the other hand, the strongest correlation for La-Nina was recorded in 1975/1976, while a weak correlation was recorded in 1973/1974. Although 1972/1973 was classified as an El-Nino year, it recorded the smallest average SSTa value of $0.06{ }^{\circ} \mathrm{C}$. This condition was due to the winter season of 1973 that was approaching the La-Nina event of 1974, which was characterised with low SST values, thus, contributing to the small SSTa value in 1972/1973.

From the selected El-Nino and La-Nina years listed in Table 2, SSTa in the SSCS was averaged according to the ENSO events. Based on Fig. 2a, a significant increase of SSTa during the onset-ElNino years was observed. In contrast, the SSTa decreased during the onset-La-Nina years (Fig. 2b). The highest SSTa peak $\left(0.85{ }^{\circ} \mathrm{C}\right)$ was recorded in January of the offset-El-Nino years. Meanwhile, the lowest SSTa peak $\left(-0.73{ }^{\circ} \mathrm{C}\right)$ was recorded in February of the offset-La-Nina years.

After recording the highest peak in the offset ElNino years, the SSTa rapidly decreased until March and stayed within a small temperature range until August (Fig. 2a). Then, the SSTa rapidly decreased again until December. Referring to the La-Nina event, the SSTa rapidly increased until July after the lowest peak was recorded in February. From July to August, the SSTa recorded a small temperature drop, before rapidly increasing until December (Fig. 2b).

\subsection{Inter-annual water temperature profile in SSCS with respect to the ENSO event}

There was a difference in the temperature value, which dominated the upper layer $(0-40 \mathrm{~m})$ of T1. In 
(a) El-Nino

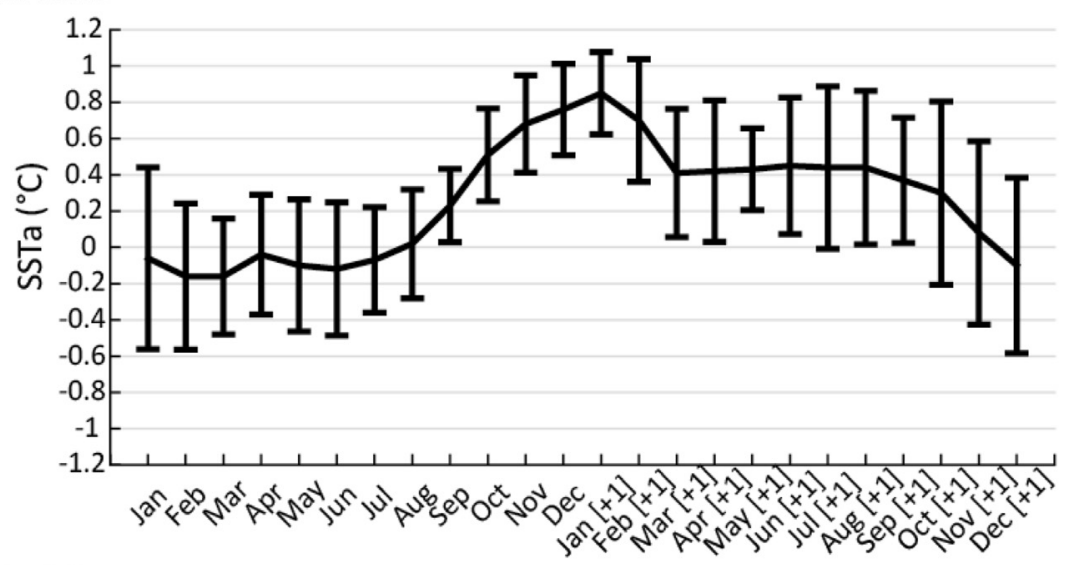

(b) La-Nina

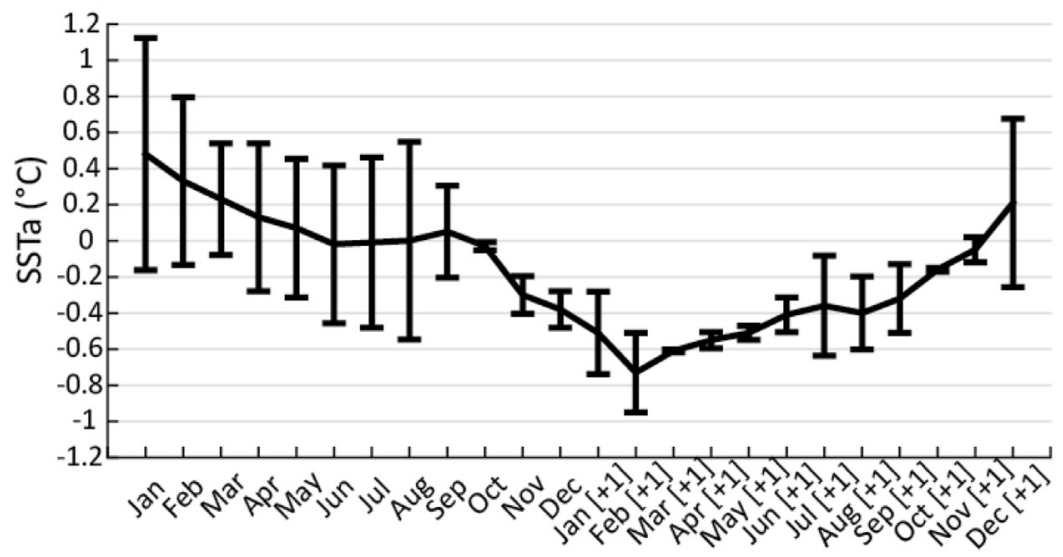

Fig. 2. Average of SSTa in the SSCS obtained from WOD for the (a) El-Nino and (b) La-Nina years. Months with the symbol ' +1 ' are in the offset-ElNino and offset-La-Nina years.

February, the dominant temperature was $26{ }^{\circ} \mathrm{C}$ (Fig. 3a), whereas, in August, it was $29^{\circ} \mathrm{C}$ (Fig. 3b) in the upper layer. Furthermore, in February, the temperature of $26{ }^{\circ} \mathrm{C}$ showed well-mixing properties from the surface until the bottom layer between 105 and $107.5{ }^{\circ} \mathrm{E}$, while between 108 and $111{ }^{\circ} \mathrm{E}$, stratification was recorded (Fig. 3a). On the other hand, the month of August showed a stable stratification between the layers along the transect (Fig. 3b).

Two episodes of El-Nino events were selected, which was in February 1972/1973 and 1982/1983 (Fig. 4). During the offset-El-Nino years (Fig. $4 \mathrm{~b}$ and d), lukewarm water $\left(27-28^{\circ} \mathrm{C}\right)$ dominated the upper layer water. Meanwhile, slightly cooler water $\left(26^{\circ} \mathrm{C}\right)$ was recorded at the upper layer water during the onset-El-Nino years (Fig. 4a and c).

For August, a consecutive episode of El-Nino and La-Nina was studied in 1976 and 1983 (Fig. 5). During the offset-El-Nino year, warm water $\left(29^{\circ} \mathrm{C}\right)$ dominated the upper layer water (Fig. 5b). Somehow, during the offset-La-Nina year, the temperature dropped until $28^{\circ} \mathrm{C}$ in the upper layer between 109 and $110^{\circ} \mathrm{E}$ and $25^{\circ} \mathrm{C}$ between 105 and $107^{\circ} \mathrm{E}$ (Fig. $5 \mathrm{a}$ ). In August during the offset-El-Nino year, there was no significant difference observed in the water column (Fig. 5). Only Fig. 5a, illustrating the offset-LaNina year, showed minimum domination of warm water at the upper layer.

\subsection{Influence of El-Nino on coastal upwelling in SSCS}

During the onset-El-Nino period at the ECPM, cold water $\left(26^{\circ} \mathrm{C}\right)$ along the longitude of $104.3-104.5$ ${ }^{\circ} \mathrm{E}$ was recorded from the bottom until the $10 \mathrm{~m}$ depth (Fig. 6a). Nonetheless, the offset El-Nino year recorded a well-mixed water temperature $\left(28{ }^{\circ} \mathrm{C}\right)$ along the transect, while the lukewarm water $\left(27^{\circ} \mathrm{C}\right)$ remained suppressed at the bottom layer (Fig. 6b). In NWSW, during the offset-El-Nino, the cold water $\left(26{ }^{\circ} \mathrm{C}\right)$ reached up to the $10 \mathrm{~m}$ depth at the 

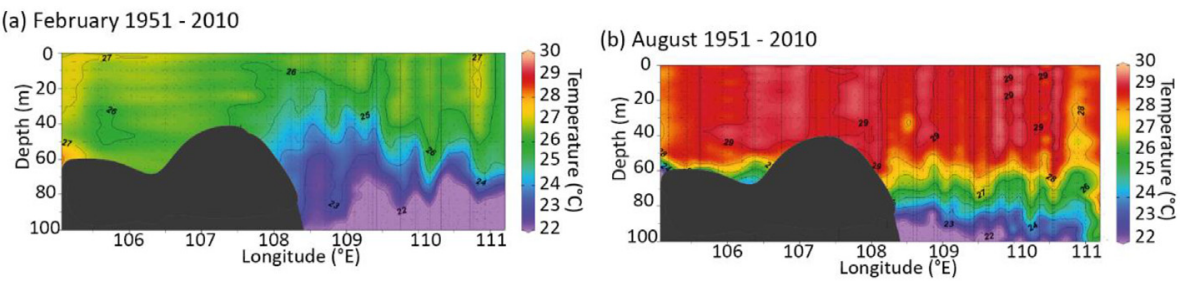

Fig. 3. Climatological observation of the water temperature profile from 1951 to 2010 at $T 1$ in (a) February and (b) August. The dots represent the datasets present.

continental shelf (Fig. 6c). Contradicting the normal year (Fig. 6d), the cold water remained at the continental slope's $40 \mathrm{~m}$ water depth.

\section{Discussion}

\subsection{Inter-annual water temperature in SSCS with respect to the ENSO event}

Based on the results in Table 2, it could be concluded that the SSTa in the SSCS was affected by the presence of El-Nino. To gain a better overview of this relationship, the SSTa trends in the SSCS from 1951 to 2010 were plotted against all the Nino indices (Fig. 7). As illustrated in Fig. 7d, Nino 4 had the strongest correlation with the SSTa in the SSCS with the smallest root mean square error (RMSE) of 0.7251. This observation was interesting since [27] reported that the Nino 3 index had the most significant correlation with the SSTa in the SCS. A possible reason for this contradicting finding could be that [27] focused on the whole SCS region, whereas this current study emphasised on the dynamics in the southern area dominated by a shallow shelf. Moreover, a good correlation between Nino 4 and the SSTa in the SSCS was possible since the Nino 4 region was the closest to the study area compared to the other Nino regions.
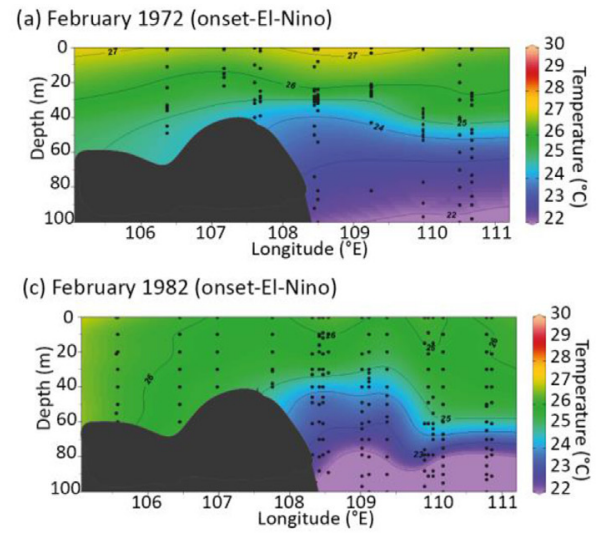

Generally, the subtropical jets during the offsetEl-Nino winters are highly intensified and more zonally symmetric than post-La-Nina winters [31]. This condition usually results in a stronger heat advection during the offset-El-Nino years compared to the offset-La-Nina years, thus, causing the highest temperature peak during the offset-El-Nino and lowest peak during the offset-La-Nina as displayed in Fig. 2. Besides, Fig. 3 and Fig. 4 have shown that the El-Nino event had resulted in the deepening of the lukewarm water temperature at the centre of the SSCS. This condition was also reported by [21]; who recorded that the MLD at the centre of the SCS deepened after the ENSO event. Moreover, in February of the offset-El-Nino year (Fig. $4 b$ and d), lukewarm water $\left(27-28{ }^{\circ} \mathrm{C}\right)$ dominated at the upper layer water along the whole transect. The warming of SCS in February of the offset-El-Nino year was a response from the positive net heat flux anomalies in November of the onset-El-Nino year, mostly due to the increase of shortwave radiation anomalies and decrease in the latent heat flux anomalies [27]. Additionally, major kinetic energy sources for the circulation in SSCS during the northeast monsoon were wind stress and kinetic energy transported by the SCSWBC [28]. During the northeast monsoon of the onset-El-Nino years, wind stress at the northern South China Sea (NSCS) was weakened, which led
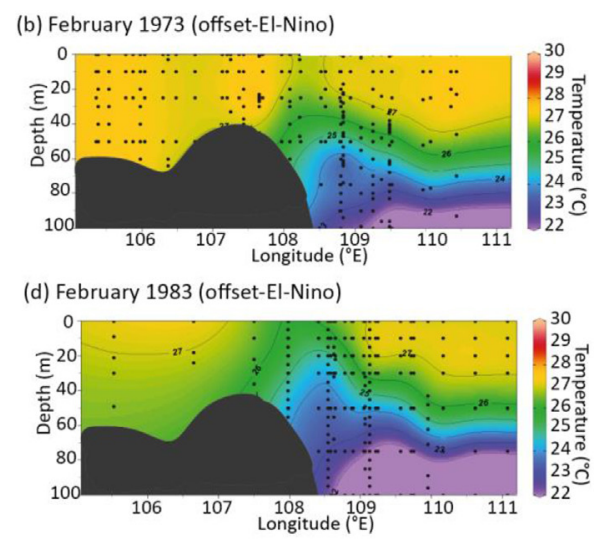

Fig. 4. Inter-annual observation of the water temperature profile at $T 1$ in (a) February 1972, (b) February 1973, (c) February 1982, and (d) February 1983. The dots represent the datasets present. 

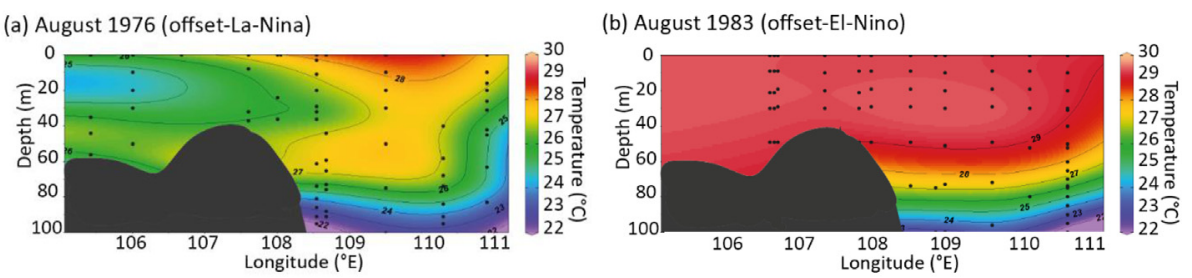

Fig. 5. Inter-annual observation of the water temperature profile at $T 1$ in (a) August 1976 and (b) August 1983. The dots represent the datasets present.

to extreme anticyclonic wind anomaly, while causing a negative SCSWBC anomaly $[28,30]$. Consequently, SCSWBC was weakened during the winter, thus, reducing the cold-water advection from NSCS towards SSCS [28,30]. This could be the reason why the SSCS recorded high water temperature at the upper layer $(0-40 \mathrm{~m})$ during the offsetEl-Nino years as illustrated in Fig. 4.

In contrast, during the westerly shear phase, the ENSO and SCS southwest monsoon were not significant, while the onset-La-Nina event caused a temperature drop in the SCS (Fig. 5a) due to frequent cold surges [40]. Furthermore, the thermocline depth anomalies are mostly negative during the El-Nino events, but positive during La-Nina events [22]. This feature might also be associated with the weakening of current circulation during the southwest monsoon of the offset-El-Nino years, which was accompanied by warm SSTa [12]. As depicted in Fig. 5b, the deepening of warm water was caused by the strength of the seawater's stability when it gained the buoyancy flux that resulted in the inhibition of thermocline deepening due to more difficult vertical convection [11,22]. Nevertheless, an inverse condition was observed in Fig. 5a, whereby the stratification of water temperature occurred during the offset-La-Nina years, which might be due to the positive features of the thermocline depth anomalies as suggested by [22].

\subsection{Coastal upwelling occurrences in SSCS based on past studies}

A smooth shelf and alongshore coastline at the ECPM could be the generating factor that enhances the coastal upwelling formation since the topographical effect could lead to a high rate of upwelling at the ECPM [6,7]. As suggested in previous studies, the coastal upwelling area at the ECPM is located within the $104.5-105.5^{\circ} \mathrm{E}$ longitude and $3{ }^{\circ} \mathrm{N}$ latitude [3,7]. Meanwhile [35,36], have reported that the upwelling area is elongated along $1-5{ }^{\circ} \mathrm{N}$ and 103.5-105 ${ }^{\circ} \mathrm{E}$. The south-westerly wind generally blows parallel along the southern and middle coast of ECPM $[17,35,36]$. Due to the influence of the
Coriolis effect, the net transport of the water is directed at $90{ }^{\circ} \mathrm{E}$ to the right of the north and northeast direction of prevailing winds, hence, providing a favourable condition for the formation of coastal upwelling in the south and centre of the ECPM due to the domination of cross-shore Ekman transport [17]. Moreover, the occurrence of Ekman pumping and Ekman transport are equally prevalent in the southern part of ECPM [17]. Regarding the estimation of upwelling strength induced by alongshore wind, the strength at the southern part of ECPM (where T2 was located) recorded the highest value of upwelling transport [17]. Based on Fig. $6 a$, the uplifting of cold water $\left(26^{\circ} \mathrm{C}\right)$ towards the subsurface layer $(10 \mathrm{~m})$ was observed in 1965 between 104 and $104.5{ }^{\circ} \mathrm{E}$ longitude. Nevertheless, suppression of upwelling occurred in August 1966, when there was no cold water $\left(26^{\circ} \mathrm{C}\right)$ present, as illustrated in Fig. $6 \mathrm{~b}$. This further strengthened the fact that the occurrence of the warm phase ENSO inhibited the coastal upwelling at the ECPM $[8,16]$. El-Nino suppressed the upwelling in the ECPM due to the slackening of prevailing winds caused by the diminishing East Asian summer monsoon provoked by the delayed ENSO effects [16]. Moreover, the north-easterly wind speed vectors anomaly during offset-El-Nino is more vigorous, and thus, it functions well to suppress upwelling in the ECPM [16].

Apart from the ECPM, the upwelling event was also documented in NWSW by [1,2,32]; and [5]; based on the analysis of chl- $a$ concentration using satellite data. NWSW (where T3 was located) was characterised with high chl- $a$ concentrations from December until April because of the strong northeasterly wind and the occurrence of coastal upwelling [1,2]. This present study conducted the first analysis of upwelling in the NWSW based on water temperature profile observation (Fig. 6c \& Fig. 6d). Upwelling in NWSW began in December, peaked in January, started to drop in February, and almost disappeared in March [32]. NWSW often recorded the highest chl- $a$ concentration during the peak northeast monsoon [5]. Higher and positive wind stress curl along with Ekman pumping during the northeast monsoon is the main key to induce the 

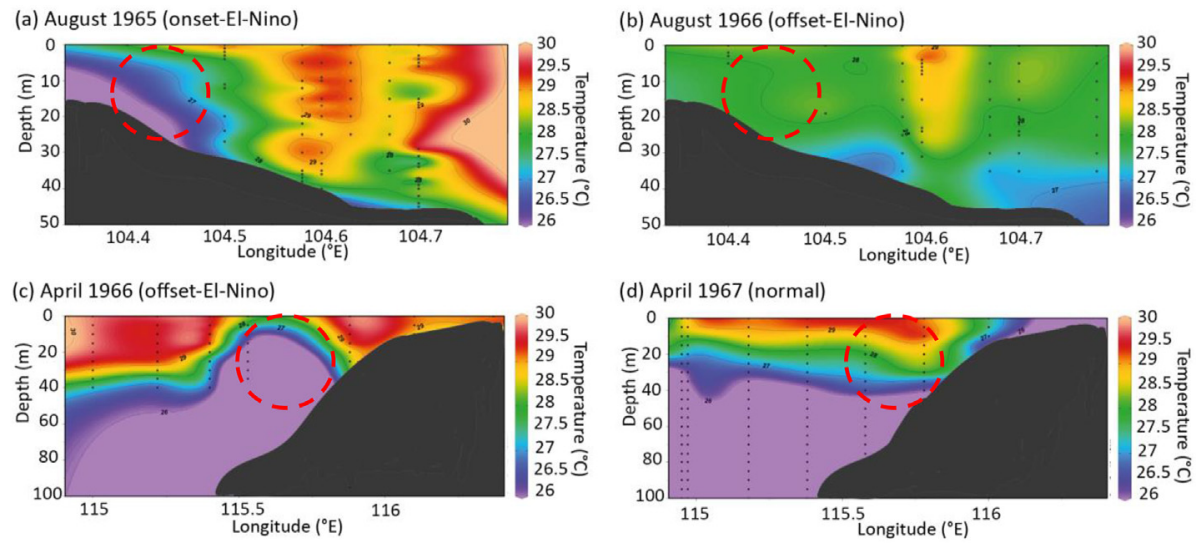

Fig. 6. Inter-annual observation of the water temperature profile at (a) T2 in August 1965, (b) T2 in August 1966, (c) T3 in April 1966, and (d) T3 in August 1967. The dots represent the datasets present, while the red-dashed circles indicate the area focused for coastal upwelling observation.

Ekman transport, which is favourable for coastal upwelling [1,2,32]. The positive wind stress curl induces upwelling, lowers the SST, and raises the chl$a$ concentration [2]. Due to cold-water advection, the upper layer water gets denser and this results in a strong vertical mixing of the mixed layer water from the surface until the bottom, while the bottom water which is highly rich in nutrients is upwelled [5]. Apart from that [32], have suggested that the upwelling shows a remarkable interannual variability under the influence of ENSO. During the northeast monsoon of onset-El-Nino years, an anticyclonic wind anomaly was established in the SCS, which behaved like a north-easterly anomaly and a positive wind stress curl anomaly was formed off the northwest coast of Borneo. These conditions enhanced the upwelling and caused anomalous surface cooling as well as a higher chlorophyll concentration.

\subsection{Observation from satellite data}

The wind is the main factor that contributes to the upwelling events at ECPM and NWSW [17,32]. Therefore, the $\mathrm{u}-\mathrm{v}$ wind components from NCEP/ NCAR Reanalysis were analysed according to the monthly average for T2 and T3. Based on Fig. $8 \mathrm{a}$ and $\mathrm{b}$, the wind direction showed an upwelling-favourable wind, which blew parallel to the shoreline and contributed to the formation of Ekman transport in the southern part of the ECPM (Fig. 6a). A high Ekman transport in the southern part of the ECPM is attributed to its location, which is closer to the zero latitude [17]. The wind direction in August 1965
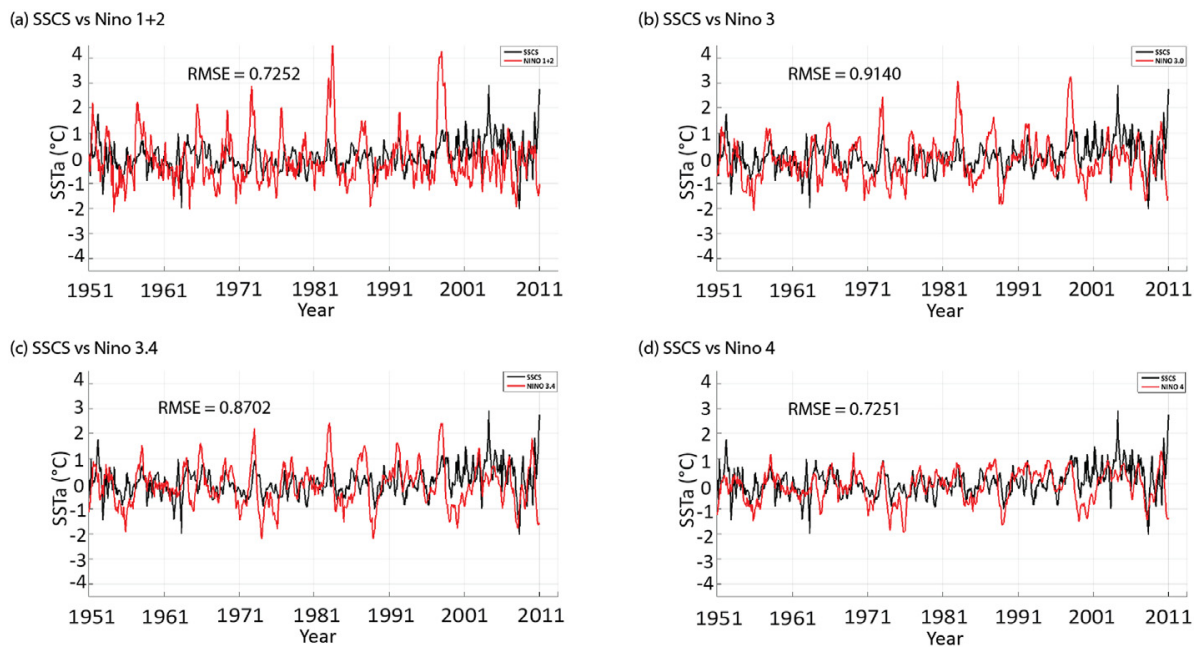

Fig. 7. Graphs of SSTa in the SSCS (red line) and Nino regions (black line) from 1951 to 2010: (a) SSCS vs Nino 1+2, (b) SSCS vs Nino 3, (c) SSCS vs Nino 3.4, and (d) SSCS vs Nino 4. 
(a) August 1965 (onset-El-Nino)

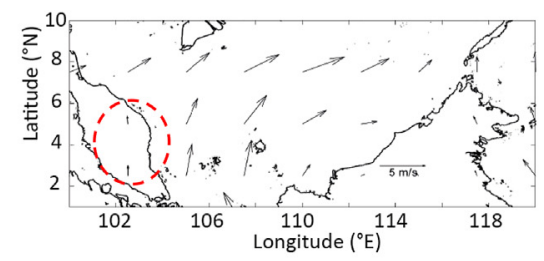

(c) April 1966 (offset-El-Nino)

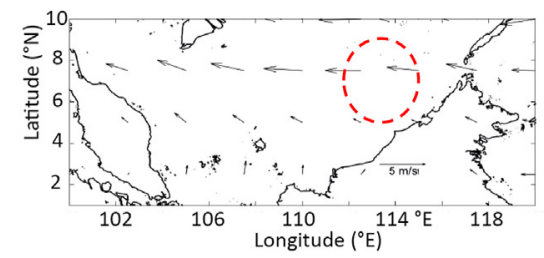

(b) August 1966 (offset-El-Nino)

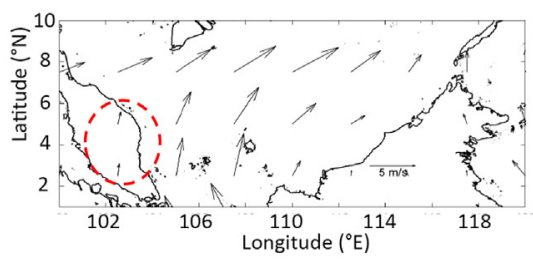

(d) April 1967 (normal)

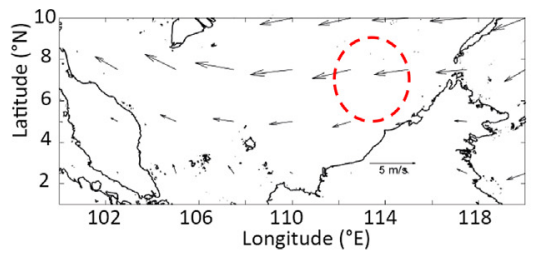

Fig. 8. Monthly average wind stress of (a) and (b) T2 and (c) and (d) T3. The red-dashed circles indicate the area focussed for coastal upwelling observation.

was slightly similar to August 1966, but the wind magnitude in August 1965 was weaker compared to August 1966. This might be due to the varying strength of the southwest monsoon between these two periods. Even though the wind magnitude was stronger during the offset-El-Nino years at the ECPM, the only process that can warm the SCS was the positive anomalous entrainment heat flux that resulted from a downward anomalous Ekman pumping velocity in the southwest monsoon [27].

For NWSW, the only available wind data were from April, an inter-monsoon period (Fig. $8 \mathrm{c}$ and d). Although both figures (Fig. 8c and d) presented the wind patterns of the same period, a different wind direction was observed. This might be due to the general characteristic of April when the wind usually varies in its direction [25]. Furthermore, Fig. 8c and $\mathrm{d}$ shows that the winds are dominated by the easterly rather than the north-easterly wind. The winds in April 1966 (Fig. 8c) recorded a slightly westward direction in comparison to the winds in April 1967 (Fig. 8d), which might be the reason for the presence of distinct upwelling features in April 1966 compared to April 1967, as demonstrated in Fig. $6 \mathrm{c}$ and $\mathrm{d}$.

Since the upwelling formation is influenced by the monsoon seasons, it is essential to seek an understanding of how ENSO could affect the monsoon intensity [40]. have proposed that ENSO can significantly impact the southwest monsoon strength at the SCS. Meanwhile [26], have stated that a strong southwest monsoon could inhibit the warm ENSO events in the SSCS. This agreed with the results obtained in this study. Uplifting of cold water was still documented in 1965, despite being classified as an El-Nino year, suggesting the role of the strong southwest monsoon in inhibiting the warm phase of ENSO at ECPM, thus, enhancing the upwelling events (Fig. 6a). Besides, the modification of the ENSO event might also result in a delayed SCS southwest monsoon onset and weak southwest monsoon in the coming year $[9,12]$, hence, retarding the upwelling formation as illustrated in Fig. 6b. On the other hand, coastal upwelling in NWSW was enhanced by the El-Nino events $[1,2,5,32]$ as demonstrated in Fig. 6c. During the northeast monsoon of the offset-El-Nino years, an anticyclonic wind behaving like a north-easterly anomaly and a positive wind stress curl anomaly strengthened in northwest Borneo [32].

\subsection{Case study of El-Nino 2009/2010}

To better understand the effect of ENSO on upwelling in the study area, the SST data from the MODIS-Aqua satellite, launched in 2002, were analysed. Due to the limited datasets from MODISAqua, 2009/2010 was selected as the El-Nino year as it has been chosen by other researchers to study the impact of El Nino in the SSCS area $[8,16]$.

Based on previous analysis, upwelling with an SST of $28{ }^{\circ} \mathrm{C}$ usually develops along the ECPM area in August [17]. As shown in Fig. 9a, a cooler SST of $28{ }^{\circ} \mathrm{C}$ only appeared at the southern part of ECPM, while upwelling appeared to be completely diminished as there was no cooler SST (Fig. 9e). This result concurred with the findings presented in Fig. 5, in which higher temperature was recorded during the offset-El-Nino years compared to the onset-El-Nino years in August.

Meanwhile, in February, usually a slightly colder SST or the colder water tongue often dominates the 


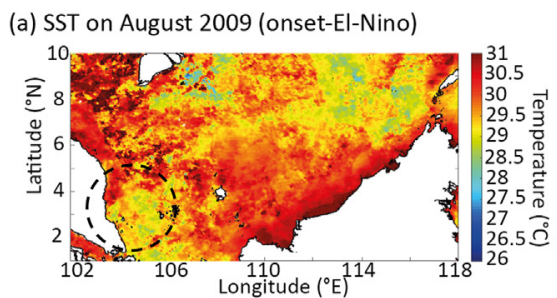

(c) SST on February 2010 (offset-El-Nino)

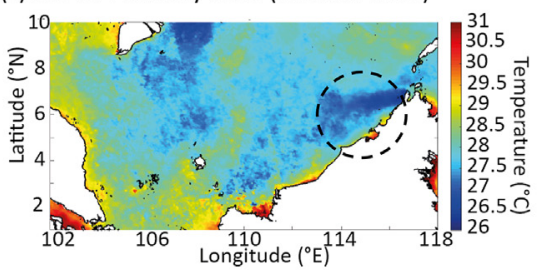

(e) SST on August 2010 (offset-El-Nino)
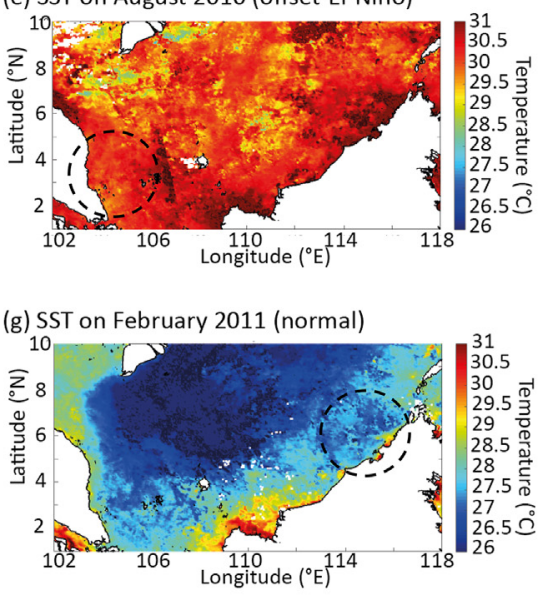

(b) Wind stress on August 2009 (onset-El-Nino)

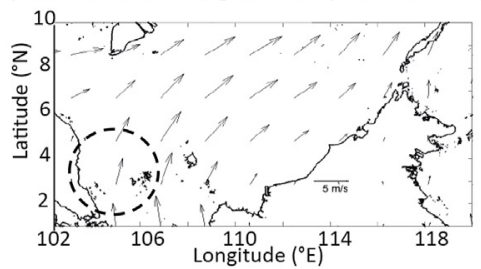

(d) Wind stress on February 2010 (offset-El-Nino)

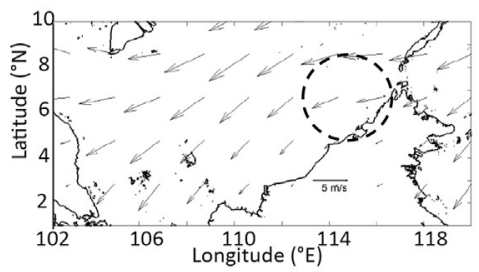

(f) Wind stress on August 2010 (offset-El-Nino)

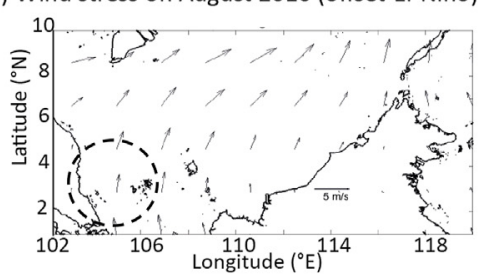

(h) Wind stress on February 2011 (normal)

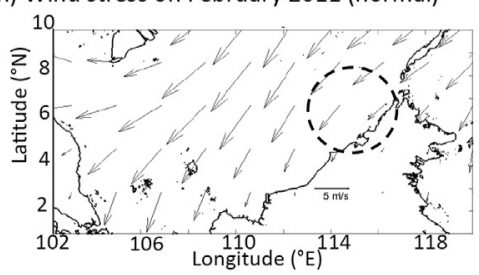

Fig. 9. Spatial distribution of SST (left panel) and surface wind stress (right panel) in (a) and (b) August 2009, (c) and (d) February 2010, (e) and (f) August 2010, and $(\mathrm{g})$ and (h) February 2011. The black-dashed circles indicate the area focused for coastal upwelling observation.

ECPM area due to the southward flow of the SCSWBC, which is located near the south of Vietnam [18]. Interestingly, upwelling in NWSW usually occurs during this month as well [32]. However, in February 2010 (Fig. 9c), which was the post-El-Nino year, the advection of the cooler water tongue was slightly intensified at NWSW as the cooler SST did not dominate in February 2011, which was a normal year (Fig. 9g).

Analysis of the wind data based on the specific ElNino year was performed, as shown in Fig. 9 (right panel). In August of the onset-El-Nino year (Fig. 9b), the upwelling favourable wind was slightly stronger compared to that in August of the offset-El Nino year (Fig. 9f). This might be the reason for the weakening of upwelling in the post-El Nino years as the wind plays a primary role in the formation of upwelling in the ECPM. Nonetheless, the northeasterly wind slightly changed its direction towards the easterly (Fig. 9d), which blew across the NWSW. This phenomenon enhanced upwelling in the
NWSW where the wind directly blew the water away from the coast, causing the water from a deeper layer to move upwards in this area. The change in the direction of the wind might be due to the anticyclonic atmospheric circulation anomaly over the SCS that develops during the ENSO years [14]. However, the north-easterly wind in the postEl Nino year was observed to be in the normal direction (Fig. 9h), whereby the wind blew parallel to the coast of northwest Sabah and generated the upwelling but with a weaker intensity compared to the previous year.

\section{Conclusions}

The SSTa of SSCS was weakly correlated with the Nino 4 index, but it was the highest among the other three Nino indices (Nino $1+2$, Nino 3, and Nino 3.4). Inter-annual SSTa of SSCS recorded the temperature increase during the onset-El-Nino years and temperature decrease during the onset-La-Nina years. 
Based on the findings, highly intensified and more zonally symmetric subtropical jets during the offsetEl-Nino years caused a strong heat advection, resulting in the highest peak reading of SSTa in SSCS. Furthermore, the increase of the shortwave radiation anomalies, the decrease of the latent heat flux anomalies, and the weakening of SCSWBC in February of the onset-El-Nino years might be the reasons for the warming of the upper layer water in SSCS, which was recorded in February of the offsetEl-Nino years. Meanwhile, the weak southwest monsoon circulation in August of the offset-El-Nino years led to the deepening of warm water temperature, which resulted in strong seawater stability as it gained buoyancy flux due to the weak vertical convection, as recorded in August of the offset-El-Nino years. At the ECPM, El-Nino induced the upwelling due to the lag of prevailing winds in the summer of the offset-El-Nino years due to the diminishing of the summer monsoon provoked by the delayed ENSO effects. On the other hand, an anticyclonic wind anomaly was established in the SCS, which behaved as a north-easterly anomaly and a positive wind stress curl anomaly off the NWSW enhanced the upwelling features in that area. Finally, regarding the extraction of data from WOD, it could provide the evidence or approval necessary for historical studies examining a large area.

\section{Conflict of interest}

There is no conflict of interest.

\section{Acknowledgement}

The authors are grateful to the Institute of Oceanography and Environment (INOS), Universiti Malaysia Terengganu (UMT), Higher Centre of Excellence (HICOE), International Collaboration Fund (ICF) from the Ministry of Science, Technology and Innovation (MOSTI), Malaysia (UMT0070814), Fundamental Research Grant Scheme (FRGS/1/2015/WAB09/UMT/03/2), and MyBrain15 scholarship for the administrative and financial support offered for this study.

\section{Appendix 1}

(b) February 1973 (offset-El-Nino)

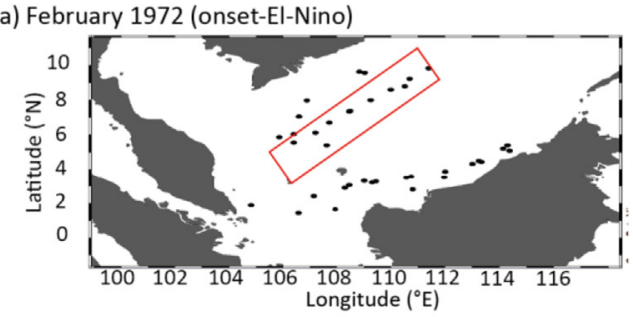

(c) February 1982 (onset-El-Nino)

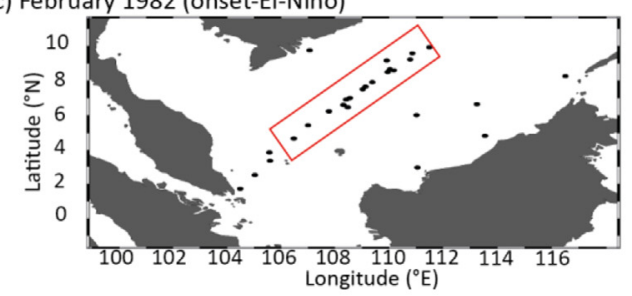

(e) August 1976 (offset-La-Nina)

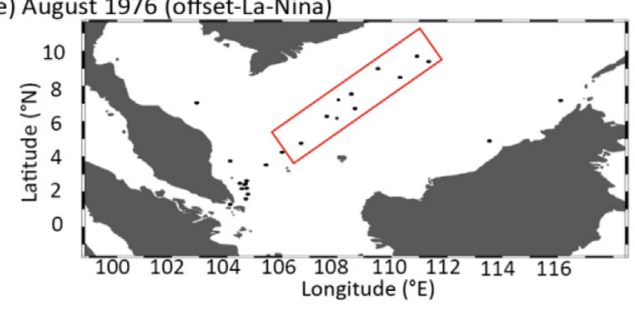

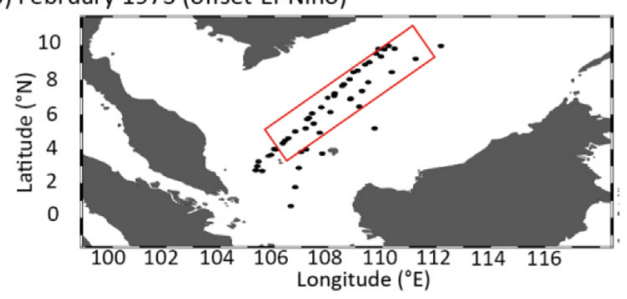

(d) February 1983 (offset-El-Nino)

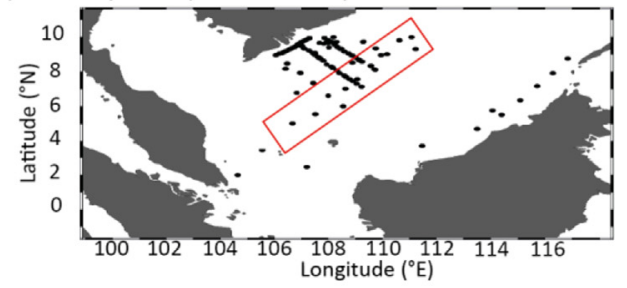

(f) August 1983 (offset-El-Nino)

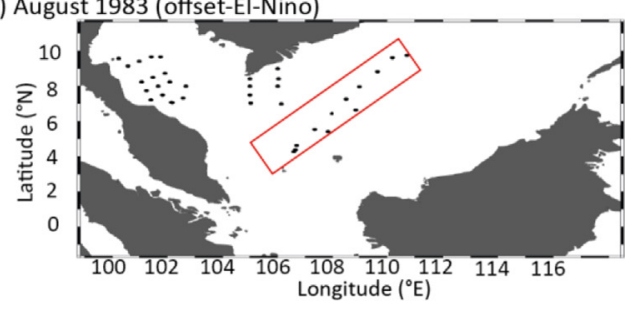




\section{Appendix 2}

(a) August 1965 (onset-El-Nino)

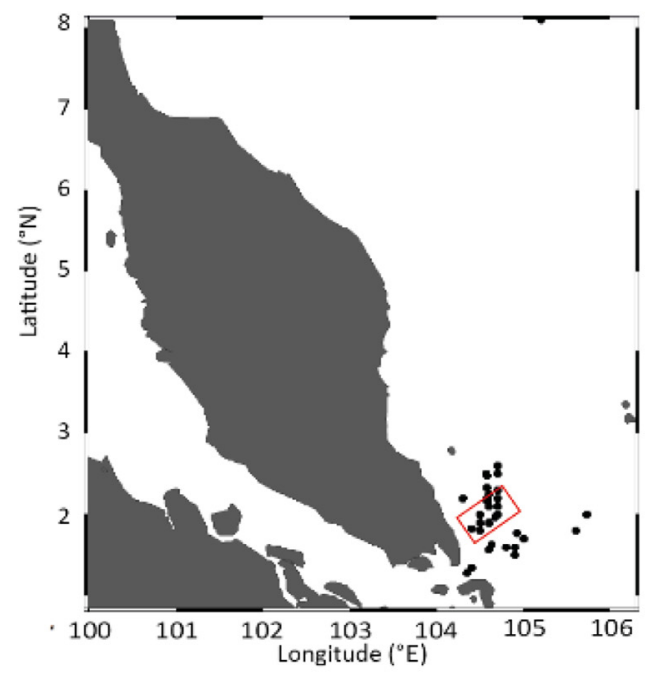

(c) April 1966 (offset-El-Nino)

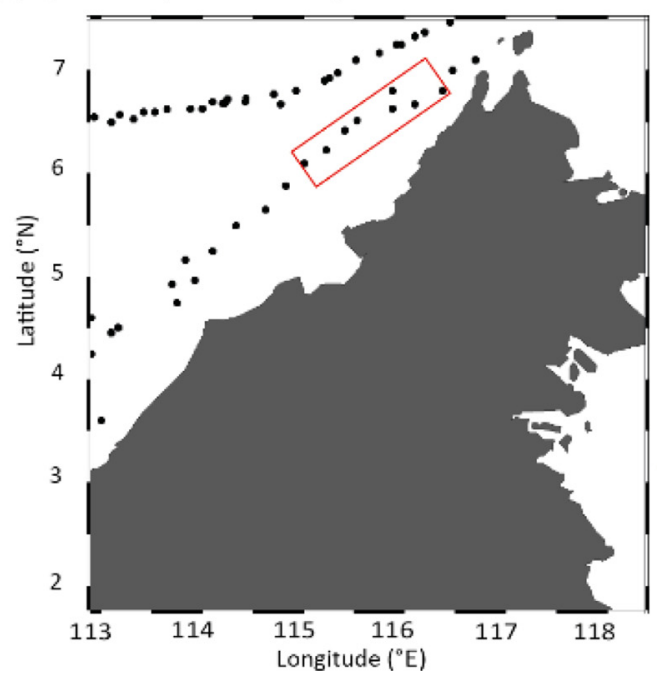

(b) August 1966 (offset-El-Nino)

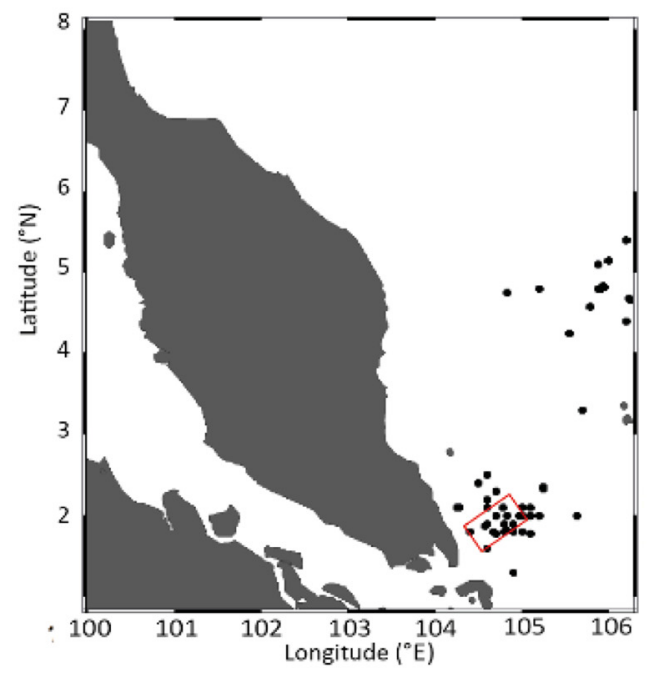

(d) April 1967 (normal)

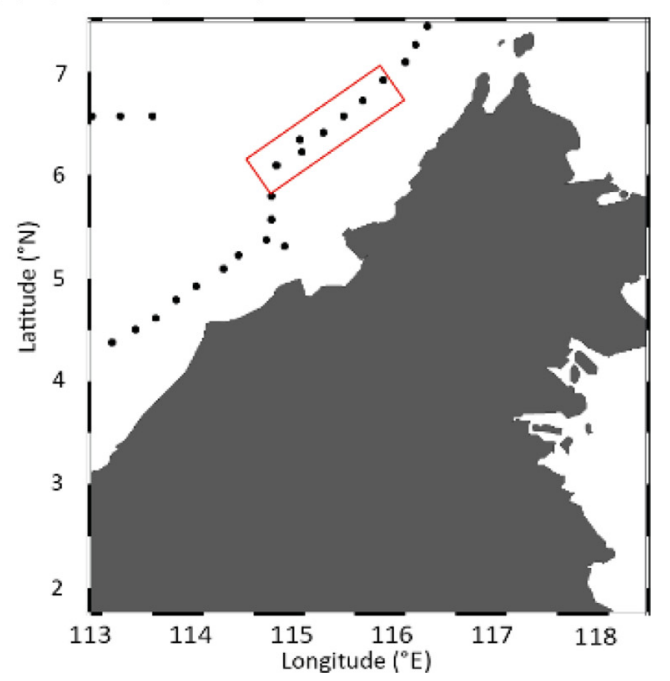

Datasets present for analysis on vertical temperature profile in $T 2(a+b)$ and $T 3(c+d)$.

\section{References}

[1] Abbas AA, Mansor SB, Pradhan B, Tan CK. Spatial and seasonal variability of Chlorophyll-a and associated oceanographic events in Sabah water. Int Workshop Earth Obs Rem Sens Appl 2012;2012 Second:215-9.

[2] Abdul-Hadi A, Mansor S, Pradhan B, Tan CK. Seasonal variability of chlorophyll-a and oceanographic conditions in Sabah waters in relation to Asian monsoon - a remote sensing study. Environ Monit Assess 2013;185(5):3977-91.

[3] Akhir MF. Review of current circulation studies in the southern South China Sea. J Sustain Sci Manag 2014;9(2): 21-30.
[4] Akhir MF, Daryabor F, Husain ML, Tangang F, Qiao F. Evidence of upwelling along peninsular Malaysia during southwest monsoon. Open J Mar Sci 2015;5(3):273-9.

[5] Chang H,W,J, Francis AS, Dayou J, Sentian J, Chee FP. Upwelling event characteristics of chlorophyll-s concentration in the surface layer of Sabah waters. Indian J Marine GeoMarine Sci 2018;47(12):2532-40.

[6] Daryabor F, Samah AA, Ooi SH. Dynamical structure of the sea off the east coast of Peninsular Malaysia. Ocean Dynam 2014a;65(1):93-106. 
[7] Daryabor F, Tangang F, Juneng L. Simulation of southwest monsoon current circulation and temperature in the east coast of peninsular Malaysia. Sains Malays 2014b;43(3): 389-98.

[8] Daud NR, Akhir MF, Muslim AM. Dynamic of ENSO towards upwelling and thermal front zone in the east coast of Peninsular Malaysia. Acta Oceanol Sin 2019;38(1):48-60.

[9] Fan Y, Fan K, Xu Z, Li S. ENSO-South China Sea summer monsoon interaction modulated by the Atlantic multidecadal oscillation. J Clim 2018;31:3061-76.

[10] Hu J, Wang XH. Progress on upwelling studies in the China seas. Rev Geophys 2016;54(3):653-73.

[11] Jacox M, Fiechter JJ, Moore AM, Edwards CA. ENSO and the California Current coastal upwelling response. J Geophys Res: Oceans 2015;120(3):1691-702.

[12] Jian M, Han P. Modulation of the connection between ENSO and the south China sea summer monsoon onset by the stratospheric QBO. In: 19th EGU General Assembly, EGU2017, proceedings from the conference held 23-28 April, 2017; 2017. Vienna 7324.

[13] Johari A, Akhir MF. Exploring thermocline and water masses variability in southern South China sea from the World Ocean database (WOD). Acta Oceanol Sin 2019;38(1):38-47.

[14] Jing Z, Qi Y, Du Y. Upwelling in the continental shelf of northern South China sea associated with 1997-1998 El niño. J Geophys Res: Oceans 2011;116:C02033.

[15] Kim WM, Yeh SW, Kim JH, Kug JS, Kwon MH. The unique 2009-2010 El Niño pool El Niño to La Niña event: a fast phase transition of warm pool El Niño to La Niña. Geophys Res Lett 2011;38(15):L15809.

[16] Kok PH, Akhir MF, Qiao F. Distinctive characteristics of upwelling along the Peninsular Malaysia's east coast during 2009/10 and 2015/16 El Niños. Continent Shelf Res 2019;184: 10-20.

[17] Kok PH, Akhir MF, Tangang F, Husain ML, Castro M. Spatiotemporal trends in the southwest monsoon winddriven upwelling in the southwestern part of the South China Sea. PloS One 2017;12(2):1-22.

[18] Kok PH, Akhir MF, Tangang F. Thermal frontal zone along the east coast of Peninsular Malaysia. Continent Shelf Res 2015;110:1-15.

[19] Levitus S, Antonov JI, Baranova OK, Boyer TP, Coleman CL, Garcia HE, et al. The World Ocean database 2013. Data Sci J 2013;12:WDS229-34.

[20] Li T, Hsu P. Tropical cyclone formation. Fundamentals of Tropical Climate Dynamics 2018:107-47.

[21] Ma J, Zhan H, Du Y. Seasonal and inter-annual variability of surface CDOM in the south China sea associated with El niño. J Mar Syst 2011;85(3-4):86-95.

[22] Peng H, Pan A, Zheng Q, Hu J. A study of response of thermocline in the South China Sea to ENSO events. Chin J Oceanol Limnol 2017;36(4):1166-77.

[23] Seidov D, Antonov JI, Arzayus KM, Baranova OK, Biddle M, Boyer TP, et al. Oceanography north of $60^{\circ} \mathrm{N}$ from World Ocean database. Prog Oceanogr 2015;132:153-73.

[24] Song W, Lan J, Liu Q, Sui D, Zeng L, Wang D. Decadal variability of heat content in the South China Sea inferred from observation data on ocean data assimilation product. Ocean Sci 2014;10(1):135-9.
[25] Taira K, Saadon MNB, Kitagawa S, Yanagi T. Observation of temperature and velocity in the coastal water off Kuala Terengganu, Malaysia. J Oceanogr 1996;52(2):251-7.

[26] Torrence C, Webster PJ. Interdecadal changes in the ENSOmonsoon system CHRISTOPHER. J Clim 1999;12(8):2679-90.

[27] Wang C, Wang W, Wang D, Wang $Q$. Interannual variability of the south China sea associated with El-niño. J Geophys Res: Oceans 2006;111:1-19.

[28] Wang W, Cai W, Zheng L, Wang D. Nonlinear meridional moisture advection and the ENSO-Southern China rainfall teleconnection. Geophys Res Lett 2018;45(9):4353-60.

[29] Wang Q, Cai W, Zhong W, Zheng L, Wu L, Wang D. Response of southern China winter rainfall to El-nino diversity and its relevance to projected southern China rainfall change. J Clim 2019;32(11):3343-56.

[30] Wang $Q$, Zheng L, Shu Y, Liu Q, Zu T, Li J, et al. Interannual variability of South China Sea winter circulation: response to Luzon Strait transport and El-Nino wind. Clim Dynam 2020; 54(1-2):1145-59.

[31] Yan X, Konopka P, Ploeger F, Tao M, Müller R, Santee ML, et al. El niño southern oscillation influence on the Asian summer monsoon anticyclone. Atmos Chem Phys 2018; 18(11):8079-96.

[32] Yan Y, Ling Z, Chen C. Winter coastal upwelling off northwest Borneo in the south China sea. Acta Oceanol Sin 2015; 34(1):3-10.

[33] Yashayaev I, Seidov D. The role of the Atlantic water in multidecadal ocean variability in the nordic and Barents seas. Prog Oceanogr 2015;132:68-127.

[34] Yashayaev I, Seidov D, Demirov E. A new collective view of oceanography of the Arctic and North Atlantic basins. Prog Oceanogr 2015;132:1-21.

[35] Zainol Z, Akhir MF. Coastal upwelling at Terengganu and Pahang coastal waters: interaction of hydrography, current circulation and phytoplankton biomass. Jurnal Teknologi 2016a;78(8):11-27.

[36] Zainol Z, Akhir MF. Coastal upwelling in the vicinity of Tioman island. Journal of Sustainability Science and Management 2016b;1:71-80.

[37] Zhang W, Vecchi GA, Murakami H, Delworth $T$, Wittenberg AT, Rosati A, et al. Improved simulation of tropical cyclone responses to ENSO in the western north pacific in the high-resolution GFDL HiFLOR coupled climate model. J Clim 2016;29(4):1391-415.

[38] Zhou LT, Tam CY, Zhou W, Chan JCL. Influence of south China sea SST and the ENSO on winter rainfall over south China. Adv Atmos Sci 2010;27(4):832-44.

[39] Zhou W, Chan JCL. ENSO and the South China Sea summer monsoon onset. Int J Climatol 2007;27(2):157-67.

[40] Zhou W, Chen W, Wang DX. The implications of El ninosouthern oscillation signal for south China monsoon climate. Aquat Ecosys Health Manag 2012;15(1):14-9.

[41] Zu T, Xue H, Wang D, Geng B, Zeng L, Liu Q, et al. Interannual variation of the South China Sea circulation during winter: intensified in the southern basin. Clim Dynam 2019; 52(3-4):1917-33.

[42] Zuo J, He Q, Chen $C$, Chen M, Xu Q. Sea level variability in East China Sea and its response to ENSO. Water Science and Engineering 2012;5(2):164-74. 